Etikonomi

Volume 14 (2), Oktober 2015

P-ISSN: 1412-8969; E-ISSN: 2461-0771

Halaman 175- 204

\title{
KONSEP RATE OF PROFIT DAN STABILITAS EKONOMI PERBANKAN SYARIAH
}

\author{
Trisiladi Supriyanto \\ Universitas Muhammadiyah Prof. Dr. Hamka \\ trisiladi.supriyanto@gmail.com
}

\begin{abstract}
.
This study aims to find the concept of rate of profit on Islamic banking that can create economic justice. Rate of profit that creates economic justice can be achieved through its role in maintaining the stability of the financial system in which there is an equitable distribution of income and wealth. To determine the role of the rate of profit as the basis of the sharing system implemented in the Islamic financial system, we can see the connection of rate of profit in creating financial stability, especially in the asset-liability management of financial institutions that generate a stable net income or the rate of profit that is not affected by the ups and downs of the market risk factors including indirect effect on interest rates. Futhermore, Islamic financial stability can be seen from the role of the rate of profit on the stability of the Islamic financial assets that are measured from the Islamic financial asset price volatility.
\end{abstract}

Keywords: rate of profit; stability; equitable distribution of income

\begin{abstract}
Abstrak.
Penelitian ini bertujuan untuk menemukan konsep rate of profit sebagai pengganti konsep bunga, pada perbankan syariah yang dapat menciptakan keadilan ekonomi. Tingkat keuntungan yang menciptakan keadilan ekonomi dapat dicapai melalui perannya dalam menjaga stabilitas sistem keuangan di mana terjadi distribusi pendapatan dan kekayaan yang berkeadilan. Untuk mengetahui peran tingkat keuntungan sebagai dasar sistem bagi hasil yang diterapkan dalam sistem keuangan Islam, kita dapat melihat hubungan rate of profit ini dalam menciptakan stabilitas keuangan terutama dalam pengelolaan aset-liability lembaga keuangan yang menghasilkan net income yang stabil atau tingkat keuntungan yang tidak terpengaruh oleh naik turunnya faktor-faktor risiko pasar termasuk pengaruh tidak langsung dari suku bunga. Selain itu, stabilitas keuangan syariah dapat dilihat dari peran tingkat keuntungan pada stabilitas nilai aset keuangan syariah yang diukur dari volatilitas harga aset keuangan syariah.
\end{abstract}

Kata kunci: tingkat keuntungan; stabilitas; distribusi pendapatan yang berkeadilan

Diterima: 30 Maret 2015; Direvisi: 3 Juni 2015; Disetujui: 10 Juni 2015 


\section{PENDAHULUAN}

Aplikasi rate of profit sebagai pengganti rate of interest (suku bunga) di perbankan syariah sering menjadi masalah karena tidak adanya tolok-ukur (benchmark) dalam penetapan profit margin pada akad jual-beli murabahah dan biaya sewa pada akad ijarah pada transaksi di perbankan syariah atau bank syariah di negara-negara Islam lainnya (El Gamal, 2006). Akibatnya seluruh aplikasi riba di lembaga keuangan syariah seperti bunga yang bersifat sederhana (simple), majemuk (compounded), fixed (tetap), variable (berubahubah) dan ditetapkan dimuka (predetermined) yang semuanya pada prinsipnya dilarang (Sa'eed, 1996), justru diterapkan pada produk-produk dengan dasar jual beli seperti murabahah dan ijarah. Selain itu terjadi perbedaan aplikasi tentang penerapan rate of profit pada akad-akad dan produk jual beli dan sewa dari sisi jangka waktu. Beberapa negara menerapkan margin (rate of profit) murabahah berjangka panjang (lebih dari 5 tahun), sedangkan beberapa negara lain menerapkan margin murabahah berjangka pendek.

Beberapa negara muslim menerapkan margin/mark up murabahah dan ujrah pada transaksi ijarah yang ditetapkan di depan (ex ante) secara fixed dalam jangka waktu panjang. Di Pakistan, murabahah dengan margin tetap dapat digunakan baik dalam jangka waktu pendek, menengah maupun panjang. Akad murabahah dapat digunakan untuk pembiayaan: pembelian bahan mentah, persediaan, peralatan, pembelian asset, pembiayaan impor, pembiayaaan expor (pre-shipment), pembiayaan barang konsumsi, pembiayaan pembelian rumah, pembelian kendaraan bermotor, pembelian tanah, pembelian toko, pembelian computer, pembelian paket wisata, pembelian paket pendidikan, pembelian paket kesehatan dan sekuritisasi asset murabahah (Usmani, 2002). Di Bangladesh, akad murabahah digunakan untuk transaksi jangka pendek sedangkan bay' mu'ajjal dengan cicilan digunakan untuk pembelian aset berjangka waktu panjang (Ahmad, 2010). Di Inggris, akad murabahah bahkan digunakan dalam transaksi pembiayaan rumah dengan jangka waktu sangat panjang 20-25 tahun (Langton, et.al, 2011). Berbeda negara, maka berbeda juga dalam mengaplikasikan akad jual belinya. 
Di antara critical issue yang menjadi penekanan dalam perdebatan konsep rate of profit sebagai pengganti rate of interest ini adalah bahwa apakah bank syariah yang menjalankan fungsi bisnisnya yang berbasis jual beli telah memasukkan unsur 'iwad atau imbal nilai (counter value) atau ziyadah (pertambahan tanpa adanya aktivitas di sektor riil) dalam penentuan rate of profit-nya. Sesuai teori rate of profit Islami, keuntungan yang diambil harus mengandung 3 unsur yaitu: 1) nilai tambah atau value addition karena adanya unsur kerja; 2) pengambilan risiko atau risk taking karena adanya risiko perubahan harga pada barang yang diperdagangkan; dan 3) penanggungan kewajiban jika terjadi kecacatan pada barang yang diperjualbelikan atau liability (Rosly, 2007).

Berkenaan dengan besarnya rate of profit, Rasulullah SAW sendiri tidak secara tegas menentukan kadar atau batasan dari keuntungan. Dalam Mejelle, Effendi Ismail Haqqi mengatakan bahwa yang dimaksud dengan keuntungan yang berlebihan adalah tidak melampaui: 1) 1/20 (5\%) dari total harga barang; 2) $1 / 10$ (10\%) dari harga hewan dan; 3) $1 / 5$ (20\%) dari harga rumah (real estate). Keuntungan yang dimaksud di sini menurut peneliti adalah profit dalam bay naqdan atau jual beli tunai (bukan jual beli tunda). Pendapat yang sama dikatakan oleh Al Ghazali, bahwa rate of profit untuk barang sebesar antara 5-10 persent dari harga barang tersebut (Ghazanfar, 2003).

Sementara ini, bank-bank syariah di pusat keuangan dunia, masih menggunakan LIBOR (London Inter-Bank Offered Rates) atau rata-rata suku bunga kredit dari bank-bank terbesar di London. Penggunaan LIBOR sebagai benchmark dipraktekkan dalam penentuan profit margin (rate of profit) murabahah atau sewa ijarah untuk produk-produk pembiayaan home financing dan commercial financing lainnya seperti pembiayaan mobil, motor dan barangbarang consumer lainnya. Sedangkan di Indonesia, perbankan syariah masih menggunakan JIBOR (Jakarta Inter-Bank Offered Rates) atau suku bunga ratarata bank-bank terbesar di Indonesia dalam penentuan suku bunga pembiayaan syariah seperti KPR, Kredit Multi Guna dan kredit lainnya. Penggunaan LIBOR atau JIBOR pada dasarnya adalah suku bunga yang dikenakan oleh 5 (lima) bank terbesar baik di pusat keuangan dunia seperti London, dalam transaksi 
pinjaman antar bank di pasar uang (money market) yang ditentukan berdasarkan kekuatan penawaran dan permintaan uang (money supply and demand) sebagai cost of funds dan bukan berdasarkan harga di pasar barang dan jasa misalnya dalam hal transaksi murabahah pembiayaan mobil atau jasa, yang diambil adalah harga sewa menyewa (ijarah) mobil sebagai Islamic benchmark.

Mahmoud A. El-Gamal mendukung penggunaan conventional benchmark yaitu LIBOR sebagai benchmark mark up pada transaksi jual beli. Penggunaan "Islamic Benchmark" tidak perlu dan tidak praktis serta berbahaya karena meskipun ia mengakui bahwa implicit rate (rate yang dikenakan sebenarnya) dalam keuangan syariah berbeda-beda tergantung dari kualitas underlying asset, tetapi benchmark Islam dalam pasar keuangan syariah ini tidak cukup mendalam dan tidak memiliki likiduitas yang baik untuk membentuk implicit rate yang uniform (seragam) sebagai patokan melakukan transaksi. Mahmoud A. El-Gamal sepertinya melihat kepada beragamnya akad yang digunakan dalam benchmark Islam seperti jual beli, sewa menyewa, kerja sama dan lain lain dibandingkan konvensional yang hanya menggunakan akad utang piutang sehingga membuat benchmark Islam lebih sulit (El Gamal, 2006).

Berbeda dengan Mahmoud A. El-Gamal, Mohsin S. Khan dan Abbas Mirakhor berpendapat bahwa dalam sistem ekonomi Islam, rate of return(rate of profit-peneliti) dalam financial asset ditentukan oleh rate of return dari bank financing yang akan digunakan sebagai benchmark (Khan dan Mirakhor, 1989). Ini berarti bahwa Mohsin S. Khan dan Mirakhor tidak setuju bahwa LIBOR yang menggunakan suku bunga dijadikan sebagai benchmark dalam keuangan syariah.

Perbedaan pendapat tentang penggunaan LIBOR yang menggunakan suku bunga, apakah bisa dijadikan sebagai benchmark dalam pasar keuangan syariah secara umum disebabkan karena penggunaan LIBOR sebagai benchmark dalam mark up akad jual beli hanya sebagai point of reference (titik acuan) terhadap cost of capital (biaya modal) dalam pasar keuangan syariah yang saat ini hidup berdampingan (co-exist) dengan pasar keuangan konvensional yang 
menggunakan prinsip time value of money dan bukan prinsip economic value of time yang mengacu kepada sektor riil.

Permasalahan rate of profit pada perbankan syariah dapat terjadi pada penentuan margin dan bagi hasil serta dalam metoda pembebanan margin (flat/efektif) dalam transaksi perbankan baik transaksi yang bersifat jual beli atau kerjasama seperti mudharabah dan musharakah. Rate of profit sebagai pengganti rate of interest juga sangat penting artinya dalam ilmu keuangan, karena perannya yang sangat sentral dalam menilai aset keuangan. Dalam ilmu keuangan konvensional, harga aset keuangan lebih besar ditentukan oleh naik turunnya suku bunga. Jika suku bunga naik, maka harga dari aset keuangan yang berbunga tetap (fixed coupon rate) akan otomatis jatuh, karena nilai present value atau harga sekarang dari aset tersebut dinilai berdasarkan nilai diskonto dari arus uang yang akan datang, dengan menggunakan tingkat suku bunga sebagai alat ukurnya.

Kebijakan yang diambil perbankan syariah dalam menentukan rate of profit atau margin pada transaksi berbasis jual-beli seperti murabahah pada dasarnya mengikuti tingkat suku bunga yang berlaku di bank-bank konvensional. Bahkan di Malaysia dan beberapa negara lain, menggunakan LIBOR (London Interbank Offered Rate) sebagai acuan dalam transaksi yang berbasis ijarah atau sewa. Oleh karena itu saat ini sudah sangat diperlukan keuangan syariah memiliki standar yang terpisah dengan bank konvensional mengingat ekonomi syariah memiliki karakteristik yang berbeda dengan ekonomi konvensional terutama dalam hal penentuan rate of profit jika dibandingkan dengan bunga. Pada dasarnya konsep rate of profit adalah konsep ex post (ditentukan imbalannya kemudian) sedangkan bunga pada dasarnya adalah konsep ex-ante atau predetermined (ditentukan imbalan sebelumnya).

Penentuan rate of profit pada produk pembiayaan syariah merupakan kunci bagi terciptanya keadilan ekonomi dalam pendapatan investasi dan kesejahteraan masyarakat dalam bentuk ringannya biaya usaha jika dibandingkan dengan menggunakan sistem bunga (rate of interest). Rate of profit pembiayaan yang berkeadilan akan menghasilkan rate of profit yang adil bagi nasabah dana mudharabah dan bank sebagai pengelola. Dalam rate of 
profit pembiayaan berupa marjin, ujrah dan bagi hasil, terdapat hak nasabah dan bank dalam sistem distribusi bagi hasil di bank syariah. Tidak seperti sistem bunga di perbankan konvensional, rate of profit nasabah dengan sistem bagi hasil di bank syariah seharusnya berpedoman kepada rate of profit atau keuntungan di sektor riil. Jika rate of profit di bank syariah mengikuti atau dibenchmark dengan rate of interest dengan sistem perhitungan pembebanan dan distribusi pendapatan berdasarkan prinsip time value of money dengan metode anuitas maka selain akan merugikan nasabah dana bahkan sebaliknya akan lebih memberatkan nasabah pembiayaan. Dengan sistem time value of money ini, yang diuntungkan hanya management bank dan nasabah deposito di awal. Oleh karena itu peneliti sangat tertarik meneliti dan menganalisa serta menemukan solusi rate of profit yang berlandaskan sektor riil pada produk pembiayaan berjangka pendek dan panjang yang bisa menciptakan keadilan yang diinginkan dalam ekonomi Islam.

Dari latar latar belakang masalah di atas, peneliti membatasi permasalah dalam penelitian ini hanya pada konsep dan aplikasi rate of profit di perbankan syariah yang menciptakan keadilan ekonomi. Pertanyaan besar yang timbul sebagai rumusan masalah dalam penelitian ini adalah: "Bagaimanakah mewujudkan konsep rate of profit di perbankan syariah yang dapat menciptakan kestabilan ekonomi”. Untuk menjawab pertanyaan besar di atas maka pertanyaan yang mengiringinya adalah: 1) Bagaimana peran rate of profit dalam menciptakan equitable distribution of income diukur dari net income dalam aset liability management bank ; 2) Bagaimana peran rate of profit dalam menciptakan equitable distribution of wealth diukur dari volatilitas nilai aset keuangan syariah.

\section{METODE}

Berdasarkan pendekatan data yang dikumpulkan, jenis penelitian ini adalah penelitian kualitatif yaitu prosedur penelitian yang menghasilkan data deskriptif berupa kata-kata, catatan-catatan yang berhubungan dengan pengertian, makna dan nilai (Kaelan, 2005). Dalam penelitian kualitatif ini, peneliti mencoba menjelaskan fakta yang sesungguhnya terjadi di lapangan mengenai aplikasi rate of profit di bank syariah baik di tingkat makro maupun 
mikro, kemudian melihat bagaimana konsep ekonomi Islam tentang rate of profit secara komprehensif. Berdasarkan tempat pelaksanaan, penelitian ini adalah penelitian pustaka dan penelitian lapangan (Teguh, 1999). Penelitian ini menyempurnakan penelitian dan aplikasi rate of profit yang telah diterapkan di lembaga keuangan syariah sebelumnya. Berdasarkan taraf pencapaian, penelitian ini adalah penelitian deskriptif (descriptive research) dan penelitian inferensial (inferential research).

Dalam penelitian ini jenis data yang digunakan adalah data primer dan sekunder. Data primer adalah adalah data yang digali dari data utamanya.Pada penelitian ini karena berhubungan dengan konsep rate of profit maka data primer diambil dari kitab-kitab fikih dan buku-buku Ekonomi Islam. Data sekunder adalah data yang diperoleh dari melalui hasil pengolahan pihak kedua dari penelitian lapangannya baik berupa data kualitatif maupun kuantitatif. Pada Penelitian ini data sekunder yang digunakan diambil dari data rate of profit Bank Syariah Mandiri (BSM) periode 2004-2009 (5 tahun).

Metode analisis penelitian ini utamanya menggunakan documentary research (documentary analysis), yaitu penelitian yang dilakukan dengan cara menganalisa data atau fakta yang disusun secara logis dari berbagai data baik primer maupun sekunder. Metode analisis lainnya adalah metode survey (survey analitik), yaitu kegiatan penelitian yang dilakukan dengan maksud untuk menarik kesimpulan guna mendapatkan arti yang lebih jauh yang tersembunyi di balik data. Untuk menguatkan konsep rate of profit yang menciptakan stabilitas ekonomi maka digunakan penelitian kuantitatif pengaruh volatilitas suku bunga yang diwakili oleh SBI terhadap pendapatan (rate of profit) di BSM selama 5 tahun.

Model yang digunakan adalah model dengan regresi berganda untuk mengetahui pengaruh rasio RSA/RSL (Rate Sensitive Asset/Rate Sensitive Liabilities), FDR (Financing to Deposit Ratio), SBI (Sertifikat Bank Indonesia), CAR (Capital Adequacy Ratio) dan NPF(Non Performing Financing) terhadap Net Margin to Deposit (NM) pada Bank Syariah Mandiri dengan bentuk model :

Net Margin $_{t}=\alpha+\beta_{1} \mathrm{RSA} / \mathrm{RSL}_{\mathrm{t}}+\beta_{2} \mathrm{FDR}_{\mathrm{t}}+\beta_{3} \mathrm{SBI}_{\mathrm{t}}+\beta_{4} \mathrm{CAR}_{\mathrm{t}}+\beta_{5} \mathrm{NPF}_{\mathrm{t}}+\mathrm{v}$ 


\section{PEMBAHASAN}

Konsep rate of profit yang dapat mewujudkan stabilitas ekonomi pada perbankan syariah yang dimaksud disini adalah konsep rate of profit yang dapat menciptakan keadilan ekonomi dalam distribusi pendapatan dan kekayaan. Rate of profit yang menciptakan kestabilan ekonomi dapat dicapai melalui perannya dalam menjaga stabilitas sistem keuangan dimana terjadi distribusi pendapatan dan kekayaan yang berkeadilan.

Peran rate of profit sebagai dasar sistem bagi hasil yang diterapkan dalam sistem keuangan Islam dapat dilihat pada hubungan rate of profit ini dalam menciptakan stabilitas keuangan terutama dalam pengelolaan asetliability lembaga keuangan yang menghasilkan net income yang stabil atau rate of profit yang akan dibagihasilkan antara nasabah dengan lembaga keuangan yang tidak terpengaruh oleh naik turunnya faktor-faktor risiko pasar termasuk pengaruh tidak langsung dari suku bunga. Oleh karena itu, kita perlu melihat: 1) Peran rate of profit ini dalam stabilitas sistem keuangan syariah yang diukur dari net income pada aset-liability management bank syariah (equitable distribution of income); 2) Peran rate of profit pada stabilitas pasar keuangan syariah yang diukur dari volatilitas nilai aset keuangan syariah (equitable distribution of wealth); 3) Melakukan verifikasi dari hasil empiris terhadap konsep rate of profit di bank syariah; 4) Analisis fikih, dengan metode documentary research, yaitu dengan cara menganalisa data atu fakta yang disusun secara logis baik dari data primer maupun sekunder. Untuk menarik kesimpulan dan arti yang lebih jauh, yang tersembunyi di balik data, penulis menggunakan metode survey analytic.

Salah satu tugas yang terpenting dari bank termasuk bank syariah adalah melakukan transformasi jatuh tempo dari aset dan liability-nya. Hampir semua bank memiliki aset berupa pembiayaan (kredit) dan investasi dalam surat berharga, yang dibiayai oleh liabilities-nya berupa giro, tabungan, deposito dan penerbitan surat berharga yang harganya ditentukan kembali (repricing) dengan jangka waktu yang lebih pendek dibandingkan aset-nya. Terjadinya apa yang disebut gap (perbedaan jangka waktu repricing) dalam aset dan liability bank ini akan berimplikasi kepada tereksposnya rate of profit (net income yang 
dapat berupa profit atau bunga) di bank pada perubahan variable pasar yang mempengaruhi aset-liability.

Sebagai contoh bank dalam menjalankan fungsi intermediasinya melakukan penawaran pembiayaan pemilikan rumah dengan akad murabahah dengan mark-up atau margin sebesar $14 \%$ per tahun secara tetap (fixed) selama 10 tahun. Untuk membiayai pembiayaan rumah ini bank melakukan penawaran investasi berupa deposito yang berjangka waktu pendek dengan jangka waktu yang bervariasi antara 1-6 bulan dengan imbal hasil sebesar ekuivalen $7 \%$ per tahun. Di sini terjadi perbedaan repricing (gap) antara aset yang yang bersifat tetap atau dengan kata lain repring dilakukan 10 tahun sekali dengan liability yang dilakukan repricing setiap 1-6 bulan sekali. Hasil bersih pendapatan (net income) bank atau lembaga keuangan lainnya (di bank konvensional disebut sebagai net interest income-NII) pada awal tahun pertama dengan demikian sebesar 7 \% p.a. Jika pada tahun kedua terjadi kenaikan suku bunga yang mempengaruhi repricing liability bank sebesar $1 \%$, maka bank tersebut pada tahun kedua telah mengalami penurunan net income menjadi 6 $\%$ p.a atau telah terjadi kerugian sebesar $1 \%$, karena lembaga keuangan tidak mampu menaikkan harga dari aset-nya akibat telah melakukan pricing yang bersifat tetap selama 10 tahun.

Risiko penurunan rate of profit karena perubahan (tidak langsung) variabel pasar seperti kenaikan suku bunga pada bank syariah akibat lebih panjangnya repricing jatuh tempo aset dibandingkan liability disebut sebagai risiko pembiayaan kembali (refinancing risk) (Hempel, et.al, 1994). Akibat sebaliknya juga dapat terjadi jika jangka waktu jatuh tempo aset lebih pendek dari liability, maka rate of profit atau net income bank (syariah) dapat turun jika terjadi penurunan pendapatan bank akibat pengaruh tidak langsung penurunan suku bunga pasar. Hal ini sering disebut sebagai risiko menginvestasikan kembali aset bank atau sering disebut sebagai reinvestment risk (Hempel, et.al, 1994). Secara umum akibat penurunan rate of profit karena pengaruh baik langsung ataupun tidak langsung suku bunga pada bank ini sering disebut sebagai spread yaitu selisih income (pendapatan) dari aset dikurangi dengan biaya liability. Pengaruh perubahan variabel pasar seperti suku bunga terhadap 
rate of profit atau net income bank syariah ini menjadi sangat penting karena 90-100 \% pendapatan bank syariah berasal dari aktivitas pembiayaan. Dengan demikian, dalam keadaan ekonomi apapun diperlukan suatu sistem keuangan yang dapat menjaga tingkat rate of profit atau net income ini dengan pertumbuhan yang stabil dan sustainable sehingga tercipta stabilitas perbankan.

Risiko lain yang sering disamakan akibat terjadinya gap antara jatuh tempo repricing aset-liability lembaga keuangan adalah apa yang disebut dengan mismatching. Mismatching adalah perbedaan jatuh tempo pada nilai pokok aset dan liability bank syariah. Lebih panjangnya jatuh tempo aset pada bank yang rata rata berupa kredit atau pembiayaan yang rata-rata di atas 1 tahun dibandingkan dengan rata-rata jatuh tempo pokok liability yang mayoritas 1 bulan menyebabkan bank mengalami risiko mismatch (ketidakcocokan jatuh tempo pokok), sehingga menyebabkan terjadinya risiko likuiditas, yang dapat menyebabkan risiko berikutnya yang lebih krusial yaitu risiko reputasi karena bank tidak mampu menyediakan likuiditas secara tepat waktu dan menyebabkan terjadinya run-off atau pengambilan besar-besaran likuiditas sehingga bank tidak bisa beroperasi lagi karena kehabisan uang kas.

Dari fakta di atas dapat disimpulkan bahwa pengelolaan net income atau rate of profit bank syariah menjadi hal yang sangat penting dalam menjaga stabilitas sektor keuangan sehingga suatu sistem ekonomi secara keseluruhan dapat berjalan dengan baik. Beberapa teori dapat dikembangkan untuk mengelola net income bank syariah agar stabil yaitu diantaranya repricing gap model dan maturity adjusted gap model agarnet income bank menjadi stabil. Selain itu, terjadinya risiko penurunan net income karena perubahan suku bunga akibat perbedaan repricing jangka waktu aset yang lebih panjang dibandingkan liability ini dapat mengakibatkan jatuhnya nilai aset (market value) dari aset berpendapatan tetap di bank sehingga dapat menyebabkan instabilitas di sektor keuangan yang lebih buruk. Teori yang dikembangkan untuk mengelola market value atau nilai aset bank ini adalah duration gap model (Resti \& Sironi, 2007). 
Stabilitas keuangan dalam suatu sistem ekonomi dapat dilihat dari beberapa faktor yaitu: 1) Tidak adanya penjaminan pengembalian pada pokok penempatan; 2) memiliki arus kas yang positif dalam ekonomi yang tumbuh; 3) Tidak menghadapi mismatchaset-liability dan 4) tidak terhubung dalam struktur pinjaman dengan bank lain sehingga dapat menyebabkan efek domino (Askari, 2010). Empat faktor ini sangat mempengaruhi kestabilan suatu sistem ekonomi.

Di bank syariah saat ini teknik pengelolaan aset and liability atau yang dikenal dengan Aset Liability Management (ALMA) risiko pengelolaan ALMA pada dasarnya sama dengan di bank konvensional, karena di bank syariah terjadi "aset liability mismatch" yang sama. Oleh karena itu Hosein Askari membuat model asetliability bank syariah yang ideal di mana tidak terdapat produk bank syariah yang didasarkan kepada akad jual-beli dan sewa seperti murabahah, istishna, salam dan ijarah. Dalam model ideal yang dikembangkan Hosein Askari, digambarkan bahwa baik dari sisi aset maupun liabilitynya kedua-duanya hanya ada produk mudharabah atau musharakah saja.

Praktek yang banyak terjadi di perbankan syariah saat ini dalam rangka membiayai proyek atau aktivitas ini, digunakan akad murabahah dengan rate of profit atau mark up yang tetap selama jangka waktu yang panjang dengan menggunakan patokan (benchmark) suku bunga bank konvensional misalkan LIBOR dan JIBOR. Aset Liability mismatch di bank syariah yang sama dengan bank konvensional akan membuat risiko ALMA nya akan sangat dipengaruhi oleh suku bunga. Jika kita menggunakan teknik keuangan syaitu "duration" sebagai alat ukur risiko pasar yang diakibatkan perubahan suku bunga, maka dapat dipastikan bahwa duration bank syariah akan selalu jauh di atas nol, karena banyaknya asetaset bank syariah yang didasarkan pada akad jual beli dengan mark up jangka panjang. Padahal seharusnya ALMA bank syariah akan menghasilkan "duration" yang mendekati nol (risk neutral). Tugas utama dari ALMA Bank Syariah seharusnya menghasilkan net income yang high quality, stabil, besar dan terus tumbuh. Oleh karena itu pengelolaan ALMA di bank syariah harus meliputi perencanaan strategis, implementasi dan proses kontrol 
terhadap volume, bauran (mixture), maturity, profit-rate sensitivity, kualitas dan likuiditas aset dan liability bank. Profit -rate sensitivity atau rate of profit sensitivity terhadap aset-liability bank syariah seperti konsep yang dijelaskan dalam penelitian ini, seharusnya berbeda dengan bank konvensional.

Secara teori, penggunaan tambahan (rate of profit) dalam jangka panjang secara tetap pada produk aset bank syariah secara masif, akan menciptakan struktur neraca yang bersifat negative gap (RSA/RSL $<0$ ) atau disebut juga positive net refinancing. Dalam kondisi suku bunga yang naik secara cepat maka kondisi ini akan mengakibatkan yang merugikan pada net income bank karena bank tidak bisa melakukan perubahan pada rate of profit asetnya (sudah fixed dalam jangka panjang). Peristiwa ini yang disebut sebagai peristiwa "negative spread" yaitu peristiwa naiknya beban bunga yang melebihi pendapatan bunga Bank. Dalam keadaan yang overheating seperti yang terjadi pada tahun 1998 di Indonesia, "negative spread" yang terjadi berkepanjangan dan jumlah yang meningkat terus menerus telah menggerus modal bank semuanya bahkan harus diselamatkan dengan Bantuan Likuiditas Bank Indonesia (BLBI) yang pada akhirnya harus di "bail out" atau diselamatkan Pemerintah dengan menerbitkan Obligasi Rekapitalisasi (Rekap Bond) sejumlah Rp 650 Triliun. Kondisi ini harus dibayar melalui pembebanan pajak kepada masyarakat. Peristiwa ini sebenarnya terulang lagi 10 tahun kemudian pada waktu terjadi krisis di Amerika pada tahun 2008 di mana suku bunga pada waktu itu juga bergerak naik dengan cepat namun tidak setinggi pada waktu 1998.

Risiko ALMA yang ditentukan suku bunga ini tentu sangat merugikan masyarakat, karena ketidakstabilan sektor keuangan dengan sistem bunga ini telah mengakibatkan ketidakseimbangan di sektor riil dan menyebabkan kesengsaraan masyarakat.

Oleh karena itu, menurut peneliti konsep rate of profit sebagai pengganti suku bunga, yang akan menentukan sensitivitas aset-liability bank syariah akan sangat menentukan net income dan kestabilan sektor keuangan 
dalam sistem ekonomi dan keuangan Islam selain faktor bauran atau komposisi aset-liability, volume, maturity, likuiditas dan kualitas aset bank syariah.

Di perbankan syariah, aplikasi yang sangat fatal tentang penggunaan transaksi murabahah terjadi dalam pembiayaan pemilikan rumah dengan margin/rate of profit yang berjangka sangat panjang (10-15 tahun) sehingga menciptakan volatility dengan "duration" yang sangat tinggi. Hal ini tentu bertentangan dengan prinsip economic value of time yang diterapkan dalam teori keuangan dan ekonomi Islam. Margin murabahah yang secara inheren berdasarkan prinsip economic value of time seharusnya bersifat jangka pendek, maka seharusnya ditujukan untuk pembiayaan jangka pendek. Rate of profit yang digunakan dalam transaksi murabahah sebagai nilai ekonomis dari waktu yang bersifat jangka pendek dan bisa di-reprice, akan menciptakan risk neutral transaksi dalam neraca bank, karena transaksi murabahah dengan rate yang variabel akan menciptakan nilai "duration" sama dengan nol.

Neraca bank syariah tetap masih menggunakan transaksi transaksi bersifat jual beli (murabahah, istishna dan salam) karena secara hukum syariah diperbolehkan oleh semua mazhab dan secara bisnis sangat diperlukan dalam rangka menawarkan varian produk yang beragam di tengah tuntutan permintaan nasabah yang sangat luas. Hal yang penting adalah bahwa transaksi berdasarkan jual beli ini tidak mengakibatkan capital loss, karena merupakan tugas bank untuk menciptakan aset liability yang stabil (Askari, 2010). Berdasarkan prinsip rate of profit yang Islami, transaksi berdasarkan akad jualbeli atau ijarah, tidak bisa digunakan untuk transaksi berjangka panjang. Semakin panjang jangka waktu, semakin besar nilai duration-nya, sehingga semakin tidak stabil terhadap perubahan rate of profit atau dampak dari bunga yang menyebabkan terjadinya capital loss.

Bervariasinya akad-akad dalam pembiayaan konsumen misalnya dalam pembiayaan pembelian rumah, mobil selain murabahah seperti musharakah mutanaqisah (MMQ) dan ijarah muntahia Bittamlik (IMBT) sebagai pengganti murabahah, dalam kajian rate of profit ini, dapat dijadikan solusi untuk menciptakan distribusi pendapatan yang berkeadilan karena rate of profit-nya dapat disesuaikan (reprice) dengan rate of profit yang terjadi di sektor riil. 
Berdasarkan prinsip ini maka seharusnya margin dalam transaksi murabahah sama dengan ongkos sewa yang dibebankan pada nasabah dengan akad musarakah mutanaqisah dan ijaroh muntahia bit tamlik jika diaplikasikan dalam produk yang sama, misalnya pembiayaan barang jadi. Dalam prakteknya rate murabahah yang dikenakan kepada nasabah berbeda dengan rate sewa yang dikenakan pada transaksi MMQ dan IMBT.

Sejalan dengan konsep rate of profit, yang tidak terekspose terhadap risiko mismatch (perbedaan jatuh tempo aset dan liability) dan risiko gap (perbedaan jangka waktu repricing), maka peneliti tidak setuju terhadap konsep pool of funds saja dalam pengelolaan aset-liability bank syariah untuk distribusi hasil usaha seperti yang dianut oleh beberapa bank syariah di negara-negara lain antara lain : Kuwait Finance House, Faysal Islamic Bank of Sudan, Al Tadhamon Islamic Bank of the Sudan, Jordan Islamic Bank, Bank syariah Malaysia Berhad (Wiroso, 2005). Peneliti lebih setuju kepada konsep gabungan antara pool of funds dan aset allocation fund karena konsep aset allocation menyebabkan duration (alat ukur risiko pasar terhadap Aset Liability Management ) mendekati nol, sehingga akan menciptakan stabilitas internal di Bank Syariah. Atau dengan kata lain neraca Bank Syariah seharusnya dikelola berdasarkan kecocokan maturity dan reprofiling dari aset dan liability-nya dan bukan berdasarkan functionality-nya saja. Pendekatan functionality dari sisi aset misalnya hanya melihat dari 2 sisi misalnya aset pembiayaan (murabahah, salam, ijarah, istishna) dan aset investasi (mudharabah, musyarakah). Sedangkan dari sisi liability hanya dilihat dari 3 sisi: demand deposit (amanah, wadi'ah), investment account (mudharabah deposit), dan Special Investment Account (mudharabah , musharakah). Management rate of profit seharusnya melihat kepada kesesuaian jangka waktu dalam pengelolaan aset-liability management-nya.

Dalam sistem keuangan ekonomi Islam yang sesuai dengan kaidah fikih yaitu yang tidak melanggar prinsip dasar riba al-fadhl maka seharusnya di bank syariah pengelolaan net income yang didasarkan atas kecocokan maturity sesuai akadnya, akan memisahkan pengelolaan bank syariah berdasarkan aset jangka pendek (murabahah, istishna dan salam), medium term investment 
(ijarah, istishna), dan kemitraan jangka panjang (mudharabah, musharakah) (Greuning \& Iqbal, 2008). Dengan sistem pengelolaan aset-liability ini maka net rate of profit bank syariah tidak akan berfluktuasi karena terjadi perubahan variable pasar. Secara teori risk management, asetliability dengan maturity profile berdasarkan repricing period yang hampir sama akan menghasil net duration yang mendekati nol atau risk netral sehingga akan kebal terhadap perubahan variable pasar seperti suku bunga. Pengelolaan berdasarkan kecocokan maturity (matched) ini juga akan memperkecil selisih profit yang dibagikan kepada nasabah setiap bulan dengan realisasi profit pada bulan berjalan untuk deposito mudharabah yang jatuh tempo tidak pada saat pembagian profit setiap akhir bulan. Pengelolaan dengan prinsip asetallocation yang sesuai dengan jangka waktu liability ini akan menetralkan posisi neraca bank syariah terhadap risiko perubahan harga pasar (market risk), seperti pengaruh tidak langsung suku bunga pada margin/mark-up, harga komoditas dan harga mata uang.

Selanjutnya dalam penentuan harga aset keuangan di lembaga keuangan seperti kredit atau pembiayaan di bank syariah, dalam aplikasinya digunakan teori Capital Asset Pricing Model (CAPM) yang dicoba disesuaikan dengan prinsip-prinsip syariah. Teori CAPM ini menyatakan bahwa dalam menentukan rate of profit (return) suatu investasi dapat dibagi ke dalam dua formula yaitu: Formula pertama mewakili imbal hasil (return) bebas risiko (risk free return) atau RF. Formula kedua adalah risk premium sebagai kompensasi karena menanggung tambahan risiko atas penempatan investor pada suatu investasi dalam periode waktu tertentu yang dihitung dari rumus : ( $\beta R m-R F)$. Formula yang pertama pada dasarnya adalah untuk mengganti unsur time value of money dan formula yang kedua adalah menyangkut risiko yang berhubungan dengan investasi pada suatu proyek atau surat berharga yang dipilih. Jika dilihat dari teori penentuan rate of profit berdasarkan CAPM ini maka unsur pertama didasarkan atas rate of interest yaitu bunga risk free rate. Dalam hal kasus di Indonesia risk free rate ini bisa diwakili oleh bunga Sertifikat Bank Indonesia (SBI). Tingkat bunga SBI ini digunakan sebagai tingkat suku bunga dasar (base rate) dan patokan tingkat bunga (benchmark rate of interest) di 
pasar keuangan dan obligasi Indonesia. SBI dianggap tidak memiliki risiko default karena BI sebagai penerbit dianggap sebagai bagian dari Pemerintah Republik Indonesia. Dalam prakteknya, BI mengeluarkan kebijakan penentuan base rate yang diumumkan kepada masyarakat sebagai bagian dari kebijakan moneternya dalam mengelola suku bunga yang dijadikan acuan bagi bank konvensional dalam menentukan harga-harga produk perbankan baik di sisi liability seperti tabungan dan deposito serta suku bunga kredit di sisi aset.

Selanjutnya dengan menggunakan dasar teori CAPM ini dilakukan pengembangan konsep untuk melakukan perhitungan suku bunga kredit di bank konvensional dengan mengggunakan suku bunga yang ditentukan di pasar uang berpatokan kepada risk-free rate (surat berharga negara seperti SBI) dan biaya-biaya lainnya seperti biaya operasional (overhead cost), risk premium dan tingkat keuntungan yang diminta oleh manajemen (spread).

Penentuan Cost of fund di bank konvensional selalu dibandingkan (benchmark) terhadap risk free rate yang ditentukan oleh Bank Sentral sebagai base rate (tingkat suku bunga acuan). Overhead Cost adalah biaya biaya yang dikeluarkan bank dalam mendapatkan dana dan spread adalah tingkat keuntungan yang dibutuhkan oleh manajemen bank dalam pengelolaan assetliability berbasis suku bunga sesuai target pemegang saham. Risk premium adalah tambahan spread yang dibebankan kepada nasabah untuk mengatasi kredit macet. Dalam aplikasinya, risk premium yang dibebankan tergantung kepada segmen pasar yang dituju oleh bank konvensional. Segmen pasar korporasi dan perusahaan besar (komersil), dibebankan risk premium yang lebih kecil jika dibandingkan dengan risk premium yang dibebankan kepada segmen usaha kecil dan mikro. Struktur harga kredit bank konvensional ini dapat menjadi ketimpangan sistem ekonomi secara struktural, karena penambahan risk premium pada struktur harga kredit hanya menguntungkan bank (pemilik modal).

Dilihat secara struktural, semua kepentingan "profit" yang ditentukan secara pasti di depan (ex-ante) kepada stake holder telah diwakili dalam struktur harga kredit. Komponen cost of fund merupakan kompensasi yang 
diberikan kepada depositor atau masyarakat penabung, yang nilainya mendekati bunga risk free return dan berbeda levelnya sesuai dengan teori liquidity preference Keynes. Produk Giro, Tabungan dan Deposito Berjangka, berbeda level suku bunganya sesuai dengan tujuan transaksi dan jangka waktunya. Giro yang digunakan untuk keperluan transaksionnal paling rendah tingkat suku bunganya dibandingkan dengan tabungan yang biasanya digunakan untuk berjaga-jaga (precaution) dan deposito untuk melakukan investasi (spekulasi menurut istilah Keynes). Deposito tingkat suku bunganya berbeda-beda yield curve-nya sesuai dengan ekspektasi suku bunga berdasarkan teori liquidity premium yang dikembangkan oleh Hicks dan Hansen (1946).

Di bank syariah yang hanya mengenal rate of profit maka penggunaan acuan cost of fund yang bersifat spekulatif dan bergerak berdasarkan dinamika di pasar uang tentu tidak sesuai dengan karakter rate of profit yang berpedoman kepada keuntungan di sektor riil. Sedangkan risk premium mencerminkan beban tambahan kepada perusahaan atau debitur, yang merupakan antisipasi terhadap kredit macet, penutupan biaya kredit macet yang bervariasi menurut jenis industri dan risiko struktur suku bunga dalam jangka waktu panjang.

Dalam prakteknya, komponen risk premium yang dikenakan pada segmen mikro dan usaha kecil jauh melebihi komponen-komponen lain pembentuk harga kredit seperti cost of fund, overhead cost dan spread. Porsi komponen risk premium ini langsung diakui sebagai pendapatan bank yang diperoleh dari tambahan premium yang dibebankan kepada semua kategori nasabah berdasarkan segmentasinya. Selain itu, praktek yang sering diaplikasikan adalah yang disebut term premium yaitu tambahan yang dibebankan secara fixed karena panjangnya jatuh tempo dari kredit. Semakin panjang jatuh temponya maka tambahan ini semakin besar. Dengan prosentasi kredit macet yang kecil, maka dari seluruh komponen pendapatan yang diperoleh dari kredit yang ditetapkan secara pasti dan predetermined (ex-ante), porsi bank atau pemilik modal dari risk premium, spread dan term premium merupakan komponen yang terbesar bila dibandingkan komponen lain, 
sehingga sistem keuangan seperti ini akan menciptakan distribusi pendapatan yang tidak adil atau di dalam istilah Quran, hanya beredar di antara orang-orang kaya saja diantara kamu.

Di lembaga keuangan syariah, tidak dikenal adanya cost of fund yang bersifat predetermined karena termasuk ke dalam transaksi riba yang hanya menguntungkan pihak pemberi dana atau investor dan tidak dikenal adanya risk premium yang ditambahkan untuk mengatasi risiko uncertainty yang dibebankan kepada pengambil pinjaman untuk menjamin kembalinya pinjaman karena hal itu berarti menghilangkan unsur risiko yang merupakan alasan diperbolehkan pengambilan profit oleh rabb al-maal (pemilik dana) dalam transaksi di sektor riil. Pendapat Samuelson ini bertentangan dengan pendapat Muhammad Baqir al-Sadr yang menyatakan bahwa risiko uncertainty (risiko tidak kembalinya modal) bukan merupakan faktor produksi dan oleh karena itu profit bukan merupakan kompensasi risiko tersebut, termasuk dalam hak rabb al-mal dalam transaksi mudharabah (Al-Sadr, 1961). Apabila di bank syariah dikenakan risk premium, maka jika nasabah lancar (tidak macet) dalam melakukan pembayaran, maka porsi ini seharusnya dikembalikan kepada nasabah. Di bank syariah, jika aktiva produktif bermasalah maka yang menanggung risiko tidak hanya dari pihak bank, tetapi juga nasabah pemilik dana karena sebagai akibat aktiva produktif yang jelek akan membawa dampak kecilnya pendapatan yang akan diterima yang akhirnya akan mengakibatkan bagi hasil yang kecil. Penanggungan risiko bisnis ini sebenarnya telah diwakili oleh komponen spread, yaitu tingkat keuntungan yang diambil sesuai risiko yang diperbolehkan, yang sifatnya harus tidak menganiayai satu sama lain atau bersifat eksploitatif.

Berbeda dengan bank konvensional, di bank syariah dalam penentuan rate of profit, seharusnya proxy tingkat keuntungan dasar yang dijadikan patokan sejak dari awal harus bersifat riil (tidak spekulatif) dan tidak eksploitatif, diambil dari keuntungan di pasar barang atau sektor riil. Dalam mengambil keuntungan di transaksi tunai di bank syariah misalnya seharusnya bukan suku bunga yang diambil di pasar uang yang dijadikan patokan. Dalam hal ini bisa dilakukan dengan mengambil salah satu pendapat di atas yang 
sesuai dengan perspektif ekonomi Islam. GDP yang merupakan ukuran tingkat output barang-barang yang dihasilkan di dalam negeri, yang dihitung berdasarkan value added produksi barang-barang nasional dapat mewakili (proxy) tingkat keuntungan minimal (rate of profit) secara nasional. Pendapat ini pada dasarnya sejalan dengan pendapat Piero Sraffa sebagai dasar perhitungan rate of profit. Selain itu dalam menghitung harga aset keuangan di bank syariah dapat ditambahkan faktor-faktor lainnya seperti di bank konvensional seperti: Over Head Cost (OHC) dan tingkat keuntungan perputaran aset dalam periode yang dinilai (Return on Asset) yang diharapkan oleh manajemen dalam tingkatan yang wajar sesuai benchmark industri. Sehingga harga aset keuangan di lembaga keuangan syariah, menurut peneliti seharusnya menjadi: GDP + OHC + ROA.

Dengan demikian, berdasarkan rumus di atas secara umum di lembaga keuangan syariah rate of profit seharusnya lebih murah dan memberikan maslahah karena memberikan kesempatan berusaha dan menciptakan distribusi pendapatan yang adil jika dibandingkan suku bunga kredit pinjaman di bank konvensional.

Pada dasarnya, semua aset keuangan memiliki arus kas berupa arus kas masuk dan arus kas keluar. Arus kas masuk dapat berupa angsuran dalam kontrak pembiayaan di bank syariah, kupon yang dibayarkan oleh penerbit surat berharga syariah dan pendapatan dari investasi di sektor riil. Arus kas masuk dan arus kas keluar bisa berupa arus kas yang bersifat tetap dan telah ditentukan di depan (fixed and predetermined-ex ante) dan bisa berupa arus kas yang bersifat tidak tetap dan ditentukan di belakang (variable andex post). Di dalam sistem keuangan Islam, arus kas yang bersifat fixed dan predetermined bisa dilihat pada transaksi yang berdasarkan akad jual beli seperti: murabahah, istishna dan salam serta transaksi yang berdasarkan akad sewa seperti: ijarah dan ijarah muntahia bit tamlik. Dikatakan fixed dan predetermined karena dalam transaksi yang berdasarkan akad jual beli seperti murabahah, istishna dan salam, margin atau mark-up ditentukan di depan dan tetap dalam jangka waktu yang ditentukan. Kalau dilihat dari sifat penambahan yang dicerminkan pada margin transaksi akad jual beli ini sama dengan transaksi pinjam 
meminjam dengan bunga tetap di bank konvensional jika ditinjau dari sifat arus kas.

Dari karakteristik transaksi yang menghasilkan arus kas yang bersifat fixed dan pre-determined, maka nilai suatu aset keuangan dapat diukur. Stabilitas nilai aset keuangan dengan demikian dapat diukur dari nilai perubahan aset tersebut terhadap benchmark (tolok ukur) yang digunakan dalam menetukan harga transaksi tersebut yang diantaranya bisa berupa suku bunga seperti yang dipraktekan yaitu dengan menggunakan LIBOR (London Inrtebank Offered Rate). Secara teori, pengukuran nilai suatu aset keuangan bisa ditentukan dengan teori Duration (Hempel, et.al, 1994). Risiko instabilitas keuangan dapat diukur dari volatilitas harga aset keuangan.

Dengan kata lain perubahan nilai aset keuangan bisa dilihat pada perubahan tolok ukur yang digunakan dalam menilai suatu aset. Sebagai contoh jika digunakan suku bunga sebagai tolok ukur maka berdasarkan rumus ini setiap perubahan suku bunga sebesar $1 \%$ maka akan menyebabkan perubahan nilai aset atau kekayaan sebesar : -1 (0.01/1.1) untuk aset yang berjangka waktu 1 tahun atau sebesar - $0.91 \%$. Jika jangka waktu yang digunakan lebih panjang misalnya 5 tahun maka risiko perubahan harga asetnya menjadi lebih besar yaitu : $-5(.01 / 1.1)=-4.55 \%$. Jadi pengelolaan aset keuangan dengan benchmark suku bunga sangat rentan terhadap penurunan kekayaan masyarakat dalam bentuk turunnya nilai aset keuangan.

Dari teori ini bisa disimpulkan bahwa akad murabahahpada transaksi pembiayaan jangka panjang, misalnya untuk pembiayaan pemilikan rumah (PPR) yang biasanya berjangka waktu 15-20 tahun memiliki volatilitas yang sangat besar yaitu antara : $13.65 \%$ untuk PPR yang berjangka waktu 15 tahun dan 18.2 \% untuk PPR berjangka waktu 20 tahun, jika mark-up atau margin yang ditetapkan bersifat tetap dan predetermined selama jangka waktu tersebut. Di sini peneliti menyimpulkan bahwa penggunaan suku bunga dalam transaksi syariah menyebabkan terjadinya instabilitas pada nilai aset keuangan yang dapat merugikan investor dan menyebabkan ketidakstabilan sistem keuangan secara keseluruhan, yaitu baik di lembaga keuangan maupun pada pasar obligasi yang di sistem keuangan syariah disebut sukuk. Sukuk berakad ijarah 
misalnya Sukuk Pemerintah Seri SR01 dengan kupon ijaroh 12 pct dengan jatuh tempo 25 Februari 2012 pernah mencapai harga 107.7199 atau mengalami apresiasi 7.7199 pct di atas harga pokok Sukuk. Sementara harga Sukuk Pemerintah Seri IF8 dengan kupon 8.8 pct jatuh tempo 15 Maret 2020 pernah mencapai harga 98.50 atau mengalami capital loss sebesar 1.5\% dari nilai pokoknya. Pergerakan harga aset financial yang dapat mengalami capital loss (turunnya kekayaan) akan menyebabkan tidak stabilnya sistem keuangan Islam, karena tidak stabilnya aset dan liability bank syariah, yang pada akhirnya berdampak pada kekayaan masyarakat yang menginvestasikan dananya di bank syariah (equitable distribution of income).

Menurut Global Association of Risk Profesionals, tingkat suku bunga yang dibebankan untuk suatu pinjaman ditentukan oleh sejumlah faktor diantaranya jangka waktu yaitu: 1) Cost of Fund; 2) Spread/margin yang dipersyaratkan untuk produk tersebut; 3) Kondisi Pasar (berapa yang dibayarkan oleh pesaing); 4) Jangka waktu berlakunya suku bunga tersebut. Bank membebankan bunga (rate of interest) pada transaksi kredit atau pembiayaan untuk berbagai kisaran jangka waktu. Permasalahan pada faktor keempat yaitu jangka waktu dalam penentuan suku bunga di bank konvensional, adalah karena suku bunga kredit dihitung berdasarkan teori Fischer yaitu The Theory of Expectation, di mana penentuan suku bunga jangka panjang diperoleh dari ekspektasi suku bunga jangka pendek di masa yang akan datang. Berdasarkan perhitungan teori Expectation ini tercipta struktur jangka waktu dari suku bunga atau yang biasa disebut sebagai yield curve berbentuk positive slope (makin panjang jangka waktu, suku bunga akan semakin tinggi). Dalam keadaan pertumbuhan ekonomi yang menurun, maka yield curve ini seharusnya berbentuk negative slope secara teori. Dalam prakteknya seperti di Indonesia, yield curve ini selalu berbentuk positive slope, dengan demikian argumen ini tidak dapat diterima karena tidak lengkap kondisinya (non exhausted condition).

Penentuan tambahan unsur term premium karena unsur waktu ini yang dibuat pada waktu awal perjanjian dilakukan tanpa berdasar atau berpedoman kepada untung atau rugi (rate of profit). Tambahan term premium pada 
margin/rate of profit murabahah tidak berubah walaupun keuntungan berlipat ganda atau sebaliknya. Tambahan term premium ini hanya mengikuti tren suku bunga yang berlaku di pasar uang dan bersifat linier berdasarkan konsep nilai waktu dari uang (konsep ex-ante dan time value of money). Dengan kata lain konsep rate of profit yang digunakan dalam margin murabahah telah mengikuti konsep rate of interest. Oleh karena itu berdasarkan analisis fikih ini, rate of profit yang diambil di depan juga harus berdasarkan keuntungan yang bersifat siklus (circular) per transaksi, yang apabila konsep ini diterapkan dalam konsep rate of profit ini adalah bahwa rate of profit dalam transaksi yang berjangka panjang harus dilakukan mark to the market (pembandingan dengan rate of profit di sektor riil) secara periodik. Dengan kata lain harus dilakukan penyesuaian harga secara periodik terhadap tingkat keuntungan di pasar barang (repricing) agar tidak terjadi praktek penambahan tanpa adanya illat/'iwad yang diperbolehkan sesuai kaidah fikih.

Selain itu penambahan secara tetap untuk suku bunga atau rate of profit dalam jangka panjang juga akan menimbulkan tindakan spekulatif. Tindakan spekulatif di lembaga keuangan konvensional dilakukan dengan cara meminjamkan uang dengan jangka waktu panjang pada saat pertumbuhan ekonomi dalam keadaan menurun, sehingga investor berharap mendapatkan keuntungan dari turunnya suku bunga secara bertahap dalam periode peminjaman. Di bank syariah, tindakan spekulatif itu dapat berupa penggunaan akad murabahah dalam transaksi jangka panjang dengan harapan tingkat margin keuntungan bank Syariah akan semakin besar seiring dengan turunnya suku bunga pinjaman di bank konvensional. Pada umumnya, pengenaan keuntungan murabahah didasarkan pada bunga pasar ditambah lagi dengan term premium, untuk mengatasi ketakutan manajemen bank naiknya suku bunga jangka panjang pada masa yang akan datang. Oleh karena itu, jika tidak terjadi kenaikan suku bunga, bank syariah akan memberikan potongan setiap bulan atau setiap tahun. Jadi potongan ini diberikan sebagai sarana untuk menyesuaikan keuntungan (rate of profit) dengan bunga pasar (rate of interest). Menurut peneliti, berdasarkan analisa 'iwad, penggunaan risk premium baik untuk mengatasi gagal bayar dan term premium untuk menutup unsur 
uncertainty jangka waktu di bank syariah, tidak bisa dipakai. Sebagai gantinya dapat digunakan rate of profit, dengan karakteristik yang bersifat circular/periodic sesuai tingkat keuntungan di sektor riil.

Rate of profit bersifat circular (berbeda dengan suku bunga yang bersifat linier), yaitu keuntungan yang berbeda-beda per periode putaran jualbeli barang atau jasa. Perputaran barang terkadang cepat berputar dan terkadang lambat. Kalau perputarannya cepat, maka keuntungannya sedikit. Jika perputarannya lambat maka keuntungannya banyak (Hosen, dkk, 2009). Unsur keuntungan dalam perputaran ini dalam struktur margin di bank syariah ini yang dimasukkan dalam komponen keuntungan dalam transaksi naqdan atau keuntungan dalam transaksi tunai. Selanjutnya dalam transaksi di bank syariah, tingkat keuntungan pada periode berikutnya dalam transaksi tunda, dapat bervariasi dan oleh karena itu rate of profit ini harus di-reprice sehingga penetapan margin keuntungan dalam transaksi murabahah (mark up) yang bersifat tetap dalam jangka waktu panjang selain bersifat riba al-fadhl juga bersifat spekulatif (maysir). Perbedaan jenis pembebanan yang dilakukan bank berdampak pada biaya pinjaman yang diberikan kepada debitur (di lain pihak berdampak pada pendapatan yang akan diterima bank).

Untuk mendukung penelitian yang bersifat kualitatif ini (berhubungan dengan konsep) peneliti melakukan verifikasi kuantitatif dengan studi empiris yang dilakukan oleh beberapa peneliti tentang pengaruh suku bunga terhadap rate of profit perbankan syariah baik di Indonesia maupun di negara-negara Islam lainnya. Untuk studi empiris di Indonesia peneliti mengambil data perkembangan rate of profit dari Bank Syariah Mandiri (BSM) dari Mei 2004 sampai Mei 2009 berdasarkan data yang diolah pada tahun 2009.

Dari hasil penelitian diperoleh hasil bahwa net income bank syariah ternyata berfluktuasi mengikuti perkembangan suku bunga dalam hal ini yang digunakan sebagai pembanding adalah suku bunga SBI (Sertifikat Bank Indonesia). Model Penelitian yang dihasilkan dalam melihat stabilitas pendapatan bersih BSM terhadap setiap perubahan suku bunga yang diwakili SBI dan faktor independen lain adalah : 


$$
\begin{array}{lrrrr}
\mathrm{NM}= & 11.270-0.015 \mathrm{RSA} / \mathrm{RSL}-0.228 \mathrm{SBI}-0.225 \mathrm{CAR} \\
\mathrm{t} & (30,285) & (-3,272) & (-10,072) & (-8,405) \\
\mathrm{SE} & (0.372) & (0.004) & (0.0023) & (0.027) \\
\mathrm{R}^{2}= & 0.801 & & &
\end{array}
$$

Dari model di atas dapat diartikan bahwa setiap kenaikan $1 \%$ suku bunga SBI akan menyebabkan penurunan rate of profit BSM sebesar $0.228 \%$. Dari data empiris ini dapat disimpulkan bahwa sifat ketidakstabilan bank syariah terhadap kenaikan suku bunga dengan struktur neraca RSA/RSL di bawah nol (negative gap) akan menghasilkan risiko yang sama dengan bank konvensional, yaitu turunnya rate of profit dari bank syariah. Dengan kata lain bahwa karakter rate of profit bank syariah bersifat sama dengan karakter NIM (Net Interest Income) bank konvensional dengan sistem bunga.

Penelitian dengan hasil yang sama dilakukan oleh Martin Cihak dan Heiko Hesse (2008) yang mengukur stabilitas sistem keuangan di 77 Bank syariah di Bahrain, Bangladesh, Brunei, Egypt, Gambia, Indonesia, Iran, Jordan, Kuwait, Lebanon, Malaysia, Mauritania, Pakistan, Qatar, Saudi Arabia, Sudan Tunisia, United Arab Emirat, West Bank dan Gaza, dan Yaman dan sebagai pembanding adalah 397 Bank Konvensional dalam periode 1993-2004 dengan menggunakan parameter z-score untuk mengukur stabilitas masing-masing bank. Parameter z-score adalah alat ukur probabilitas nilai aset bank menjadi turun karena naiknya nilai liabilitas. Z-score dapat diformulasikan sebagai perbandingan $(\mathrm{k}+\mu) / \alpha$ dimana $\mathrm{k}$ adalah modal dan cadangan sebagai persentase dari aset, $\mu$ adalah rata-rata profit sebagai persentasi dari aset dan $\alpha$ adalah standard deviasi dari imbal hasil aset sebagai proxy dari volatilitas imbal hasil. Dari hasil penelitian ini, diperoleh hasil bahwa bank syariah yang besar cenderung lebih tidak stabil bila dibandingkan dengan bank konvensional yang besar, yang dihitung dari zscorenya. Salah satu penjelasannya adalah bahwa bank syariah yang besar lebih sulit untuk melakukan penyesuaian terhadap asetnya dalam perubahan profil risikonya. Di dalam penelitian tersebut tidak dijelaskan alasannya secara jelas penyebab ketidakstabilan bank syariah yang diteliti. Menurut peneliti, kesulitan perubahan itu terutama kesulitan untuk merubah struktur aset yang 
sebagian besar memiliki rate of profit yang bersifat tetap dan berjangka panjang sehingga terjadi penurunan terhadap parameter profit $\mu$ karena terjadinya perubahan variabel pasar (suku bunga) yang mempengaruhi secara tidak langsung terhadap liabilitas berupa meningkatnya permintaan imbal hasil dari deposito mudharabah-nya.

Penelitian lainnya yang dilakukan oleh Amine Abi Aad dan Elias Raad (2009) antara tahun 2003-2007 khususnya di negara negara Timur Tengah yaitu di Bahrain, Jordan, Kuwait, Lebanon, Qatar, Saudi Arabia, Syria, United Emirat Arab, dan Yaman terhadap 83 konvensional bank dan 20 Bank syariah rata-rata net profit di Bank syariah lebih rendah 3\% dibandingkan dengan net interest margin di bank konvensional yang sekitar $6 \%$. Menurut peneliti hal ini terjadi karena antara periode 20032007 terjadi kenaikan tingkat suku bunga secara umum (lihat Gambar 4.9), sehingga dalam kondisi banyaknya transaksi murabahah di negara-negara Timur Tengah menyebabkan bank bank syariah di negara-negara tersebut tidak dapat meningkatkan pendapatannya, yang dapat dilihat dari lebih rendahnya AROA (Average Return on Asset) atau rata rata return pendapatan dari aset bank syariah di negara-negara tersebut jika dibandingkan dengan bank-bank konvensional.

Secara fikih, sesuai dengan kaedah riba al-fadhl, benchmarking akad jual beli murabahah dengan menggunakan LIBOR atau JIBOR telah melanggar kaedah mark to the market atau melakukan pembanding terhadap komoditas yang sama dengan pembanding di pasar uang sehingga dapat dikategorikan sebagai melakukan riba. Seharusnya dalam melakukan mark to the market atau benchmarking digunakan harga sewa barang yang dijadikan jual beli pada akad murabahah pada pasar sewa (leasing) di sektor riil, dan dilakukan repricing minimal 1 tahun sekali.

Dalam prakteknya bank syariah dalam rangka memitigasi risiko uncertainty dalam jangka panjang maka dalam hal penentuan rate of profit-nya menerapkan tambahan atas risiko naiknya rate of interest dengan menambahkan mark up secara tetap dalam jangka panjang (di atas 5 tahun). Praktek ini menyebabkan bank syariah sebenarnya telah melakukan spekulasi 
(maysir) terhadap nilai mark up tersebut. Wujud maysir dalam aplikasi rate of profit di bank syariah adalah penambahan margin untuk menghindari kerugian karena adanya unsur uncertainty (ketidakpastian), dimana unsur ketidakpastian karena unsur waktu yang dibebankan kepada nasabah ini berupa tambahan keuntungan yang bersifat fixed dalam jangka panjang. Penambahan margin yang bersifat fixed dalam jangka panjang, pada dasarnya suatu permainan (spekulasi) yang bersifat "zero sum game" terhadap prediksi tingkat rate of profit (suku bunga) dalam jangka panjang.

Syariah dalam prinsip-prinsipnya sebenarnya mengenal istilah risiko (risk) dan ketidakpastian (uncertainty) berkaitan dengan hasil investasi dan keputusan bisnis karena hasil memang tidak bisa diketahui secara pasti sebelum terjadi. Walaupun orang-orang bisa memprediksikan masa depan tetapi tidak seorangpun mengetahui seperti apa masa depan itu. Dengan demikian bisnis berisiko ketika hasil dari bisnis tersebut tidak pasti. Biasanya risiko berkaitan dengan bermacam-macam kemungkinan hasil yang diperoleh, ada kemungkinan rugi dan ada kemungkinan untung.

Rosly (2007) membedakan risiko dan ketidakpastian (uncertainty) yang dibolehkan dalam syariah dan resiko dan ketidakpastian (uncertaity) yang tidak dibolehkan. Rosly menjelaskan bahwa risiko dan ketidakpastian dalam akad (transaction) dikatakan gharar dan risiko dan ketidakpastian dalam hasil bisnis(business out comes) dikatakan ghurm. Ghurm adalah fitrah dalam dunia usaha karena tidak seorangpun dapat menolak terjadinya ghurm oleh sebab itu diperlukan kehati-hatian dalam menterjemahkan kata risk dan uncertainty (gharar dan ghurm). Ghurm (risk) berkaitan dengan risiko dan ketidakpastian dalam hasil bisnis (business outcomes) sedangkan gharar terkait dengan risiko dan ketidakpastian dalam kontrak perjanjian (contractual agreements). Transaksi yang mengandung unsur ghurm halal hukumnya sedangkan transaksi yang mengandung unsur gharar menjadi haram. Transaksi yang mengandung risiko dan ketidakpastian dalam hasil bisnis dibolehkan oleh syariah. Risiko dan ketidakpastian yang tidak dibolehkan dalam syariah adalah risiko dan ketidakpastian dalam kontrak. 
Dalam prakteknya, bank syariah menambahkan unsur uncertaintyrate of profit dalam jangka panjang dalam akad, padahal tambahan ini bersifat tidak jelas bagi kedua belah pihak sehingga tambahan ini mengandung unsur gharar. Adanya tambahan pada transaksi murabahah jangka panjang di bank syariah menjadi penyebab harga produk bank syariah menjadi lebih mahal dibandingkan bank konvensional. Hal ini disebabkan karena pada dasarnya di dalam praktek di bank konvensional, rate of interest yang dikenakan kepada nasabah bisa secara sepihak dirubah oleh bank konvensional sehingga rate of interest yang digunakan pada awalnya selalu lebih rendah dibandingkan dengan bank syariah. Di lain pihak bank syariah secara akad, pada transaksi murabahah hanya boleh menggunakan satu rate of profit dan tidak boleh dilakukan penyesuaian atau repricing.

Dampak penggunaan transaksi murabahah secara masif dalam sistem keuangan syariah, selain akan menurunkan pendapatan nasabah dan penurunan kekayaan nasabah dalam keadaan suku bunga yang tidak menguntungkan juga dapat menurunkan investasi karena naiknya biaya modal (cost of capital) dan menurunnya akumulasi modal (Ismail, 2010). Penghapusan spekulasi pada komponen keuntungan transaksi jual-beli dan sewa pada sistem keuangan syariah akan menciptakan stabilitas keuangan pada harga-harga aset keuangan syariah dan menciptakan distribusi pendapatan yang adil baik pada pemilik modal maupun pengusaha sehingga diharapkan akan terjadi full employment dan sustainable growth yang akan menciptakan kemakmuran masyarakat secara luas.

\section{SIMPULAN}

Peran rate of profit dalam menciptakan equitable distribution of income yang diukur dari net income pada aset-liability management bank syariah, akan memisahkan pengelolaan bank syariah berdasarkan aset jangka pendek, medium term investment, dan kemitraan jangka panjang. Dengan sistem pengelolaan aset-liability ini maka net rate of profit bank syariah tidak akan berfluktuasi karena terjadi perubahan variabel pasar. Peran rate of profit dalam menciptakan equitable distribution of wealth dapat dilihat dari volatilitas nilai aset keuangan syariah yang lebih stabil 
jika menggunakan konsep fikih yang sesuai dengan prinsip-prinsip syariah. Dari analisa ekonomi dan fikih dapat dilihat dari komponen risk premium yang ditambahkan dalam struktur harga aset keuangan syariah adalah tambahan yang sama dikenakan pada transaksi pinjaman berdasarkan kredibilitas peminjam hanya karena menunggu waktu disebabkan adanya risiko default dan biaya yang akan dikenakan untuk melakukan penagihan jika pinjaman tersebut benar-benar macet.

\section{PUSTAKA ACUAN}

Ahmad, A.U.F. 2010. Developments in Islamic Banking Practice: The Experience of Bangladesh. Florida: Universal Publisher.

Askari, H, et.al. 2009. New Issues in Islamic Finance and Economics: Progress and Challenges. Singapore: John Wiley \& Sons.

Askari, H, et.al. 2010. The Stability of Islamic Finance: Creating a resilient Financial Environment for a secure future. Singapore: John Wiley \& Son Finance.

Bank Indonesia. 2010. Krisis Global dan Penyelematan Sistem Perbankan Indonesia. Jakarta: Bank Indonesia.

Bessis, J. 2010. Risk Management In Banking (Third Edition), Chicester, West Sussex, England: John Wiley and Sons Ltd.

Cihak, M. \& H. Hesse. 2008. Islamic Banks and Financial Stability: An Empirical Analysis. Kuala Lumpur: International Monetary Fund Working Paper.

El Gari, M.A. 1993. Towards An Islamic Stock Market. Islamic Economics Studies, Vol. 1 No. 1, IRTI-IDB, (Desember 1993), http://www.irti.org.irj/go/km/ docs /documents /IDB (diakes 15 Mei 2010).

El-Gamal, M.A. 2006. Islamic Finance: Law, Economics and Practice. New York : Cambridge University Press.

Ghazanfar, S.M. 2003. Medievel Islamic Economic Thought: Filling the "Great gap" in European Economics. London: Routledge Curzon. 
Hempel, G.H. et.al. 1994. Bank Management; Text an Cases .New York: John Wiley \& Sons.

Ismail, A.G. 2010. Money, Islamic Banks and the Real Economy.Kuala Lumpur: Cangeage Learning.

Khan, M. \& A. Mirakhor. 1989. The Financial System and Monetary Policy in an Islamic Economyi Journal of Reasearch in Islamic Economics, Vol. 1 (1989),

http://www.kau.edu.sa/Files/320/Researches/51007_21144.pdf

Langton, J, et.al Turkistani. 2011. Islamic Economics and Finance: A European Perspective. Hampshire UK: Palgrave Macmillan.

Raad, A.A.A. \& Elias. 2009. The Battle of Islamic and Commercial Banks: Are Islamic Banks More Cost, Revenue and Profit Efficient than Commercial Banks: an Empirical Comparative Study from the Middle East. Saarbrucken, Deuscthland: Lebanese American University.

Resti, A \& A. Sironi. 2007. Risk Management and Shareholders' Value in Banking: From Risk Measurement Models to Capital Allocation Policies. Chicester, West Sussex, England: John Wiley \& Sons Ltd.

Riyadi, Slamet. 2006. Banking Assets and Liability Management. Jakarta: Lembaga Penerbit Fakultas Ekonomi Universitas Indonesia.

Rosly, S.A. 2005. Islamic Interbank Money Market: Critical Issues on Islamic Banking and Financial Markets. Kuala Lumpur: Dinamas Publishing.

Teguh, M. 1999. Metodologi Penelitian Ekonomi: Teori dan Aplikasi. Jakarta: PT. Raja Grafindo Persada.

Usmani, M.I.A. 2002. Meezanbank's Guide to Islamic Bank. Karachi Pakistan: Darul Ishaat.

Usmani, M.T. 1998. An Introduction to Islamic Finance. Karachi, Pakistan: Maktaba Ma'ariful Qur'an. 
Van Greuning, H. \& Z. Iqbal. 2008. Analysis for Islamic Bank. Washington: World Bank.

Wiroso. 2005. Penghimpunan Dana dan Distribusi Hasil Usaha Bank Syariah. Jakarta: PT Gramedia. 